\title{
THỜI GIAN SỐNG THÊM SAU MỔ CẮT KHỐI TÁ TỤY VÀ CÁC YẾU Tố LIÊN QUAN
}

\section{TÓM TẮT}

Mục tiêu: Thời gian sống thêm sau mổ và các yếu tố liên quan ở bệnh nhân phẫu thuật cắt khối tá tụy. Đối tượng và phương pháp nghiên cứu: nghiên cứu mô tả hồi cứu 84 trường hợp được phẫu thuật cắt khối tá tụy để điều trị các tổn thương ắc tính ở vùng đâu tưy tá tràng và quanh bóng Vater tại Bênh viên Bạch Mai từ 2016 đến 2020. Kết quả nghiển cứu: 84 trường hợp từ 26 đến 80 tuổi, 47 nam và 37 nữ, đô tuổi trên 40 là chủ yếu $(92,5 \%)$. Ung thư Vater $52,4 \%$, ung thư đầu tụy $23,8 \%$, ung thư đường mât $19,0 \%$. Thời gian sống thêm sau mổ cắt khối tá tụy trung bình là 36,2 tháng; tỉ lệ sống thêm sau mổ î tháng là $92,1 \%, 36$ tháng $45,6 \%, 60$ tháng là $24,7 \%$. Thời gian sống thêm sau mố liên quan với nhóm tuổi (> 65 tuổi vs. $\leq 65$ tuổi), hạch (N1 vs. N0). Kết luận: Phấu thuật cắt khối tá tụy an toàn và hiệu quả. Thời gian sống thêm sau mổ trung bình là 36,2 tháng, thời gian sống thêm sau mổ liên quan đến nhóm tuổi, giai đoan hach.

\section{SUMMARY \\ LONG TERM SURVIVAL FOLLOWING PANCREATICODUODENECTOMY AND THE FACTORS RELATED}

Objective: Long term survival following pancreaticoduodenectomy and identifying the factors related for patients with periampullary tumors. Subjects and research methods: records collected over a five-year period from 84 patients that underwent pancreaticoduodenectomy at Bach Mai Hospital from 2016 to 2020. Results: Eighty-four patients aged 26-80 years were included, 47 men and 37 women. Ambullary adenocarcinoma 52,4\%, pancreatic adenocarcinoma $23,8 \%$, cholangiocarcinoma $19,0 \%$. The average survival after surgery is 36,2 months, 12 months after surgery $92,1 \%$ patients still alive, in 36 months 45,6\%, 60 months 24,7\%. The factors associated with the risk of death following surgery were tumors at the N1 stage, an age > 65 years. Conclusion: Pancreaticoduodenectomy procedure for the treatment of periampullary tumors were performed safely, the factors associated with an increased risk of death following surgery included tumors at the N1 stage, an age greater than 65 years old.

\section{I. ĐĂT VẤN ĐỀ}

Khối u ắc tính vùng đầu tụy tá tràng và quanh bóng Vater là tổn thương thường gặp, các

*Bệnh viện Bạch Mai

Chịu trách nhiệm chính: Trần Mạnh Hùng

Email: tranmanhhungngoaibm@gmail.com

Ngày nhận bài: 14.5.2021

Ngày phản biện khoa học: 6.7.2021

Ngày duyệt bài: 19.7.2021

\section{Trần Mạnh Hùng*}

triệu chứng lâm sàng thường nghèo nàn và mơ hồ làm cho việc chẩn đoán và điều trị bệnh chậm trễ. Phẫu thuất vẫn là biện pháp điều trị cơ bản, phẫu thuật cắt khối tá tụy để điều trị các khối u vùng đâu tụy tá tràng và quanh bóng Vater là phẫu thuật lớn, phức tạp, tiên lượng bệnh phụ thuộc việc chẩn đoán và chỉ định điều trị sớm hay muộn. Tại Khoa Ngoại tổng hợp Bệnh viên Bạch Mai đã phẫu thuật cắt khối tá tụy cho nhiều trường hợp. Nghiên cứu này nhằm mục tiêu: Đánh giá thời gian sông thêm sau mổ và các yêu tố liên quan ở bênh nhân phẫu thuật cắt khối tá tụy để điều trị các khối u ăc tính vùng đầu tụy tá tràng và quanh bóng Vater.

\section{II. ĐỐI TƯợNG VÀ PHƯƠNG PHÁP NGHIÊN CỨU}

\section{1. Đối tượng}

\section{Tiêu chuẩn lứa chon}

- Bệnh nhân được mổ cắt khối tá tụy tại Bệnh viện Bạch Mai từ 2016 - 2020

- Có kết quả giải phẫu bệnh sau mổ là tổn thương ác tính ở đầu tụy tá tràng và quanh bóng Vater: Ung thư bóng Vater, đầu tụy, tá tràng hay ống mật chủ...

- Được kiểm tra, đánh giá sau phẫu thuật, có thông tin còn sống hay đã mất

\section{Tiêu chuẩn loại trừ}

- Được phẫu thuật cắt khối tá tụy nhưng kết quả giải phẩu bệnh sau mổ không phải là ung thư

- Mất các thông tin về người bệnh

2. Phương pháp nghiên cứu: Nghiên cứu mô tả hồi cứu, số liệu được sử lý bằng phần mềm SPSS.

\section{KẾT QUẢ NGHIÊN CỨU}

Tổng số 84 bệnh nhân được phẫu thuật cắt khối tá tụy đảm bảo đủ các tiêu chuẩn được đưa vào nghiền cứu.

\begin{tabular}{|c|c|c|}
\hline Đặc điếm bệnh nhân & n (84) & Tỉ lệ (\%) \\
\hline Giới: $\quad$ Nam & 47 & 55,9 \\
\hline Nữ & 37 & 44,1 \\
\hline Tuối: $20-39$ & 4 & 4,8 \\
\hline $40-59$ & 40 & 47,6 \\
\hline$\geq 60$ & 40 & 47,6 \\
\hline BMI: $\geq 25$ & 4 & 4,8 \\
\hline$<25$ & 80 & 95,2 \\
\hline ASA: & 11 & 13,1 \\
\hline 2 & 57 & 67,9 \\
\hline 3 & 16 & 19,0 \\
\hline
\end{tabular}




\begin{tabular}{|c|c|c|}
\hline \multicolumn{3}{|l|}{ Bệnh kèm theo } \\
\hline Đái đường & 22 & 26,1 \\
\hline Cao huyết áp & 9 & 10,7 \\
\hline Hô hấp & 9 & 10,7 \\
\hline Tim mạch & 8 & 9,5 \\
\hline \multicolumn{3}{|l|}{ Phương pháp phầu thuât } \\
\hline Phấu thuật mơ (PT mở) & 62 & 73,8 \\
\hline Phâu thuật nội soi (PTNS) & 22 & 26,2 \\
\hline
\end{tabular}

Nhânn xét: Bênh hay gặp ở nam nhiều hơn nữ, trên 40 tuổi là chủ yếu, 26\% các trường hợp có đái đường kèm theo.

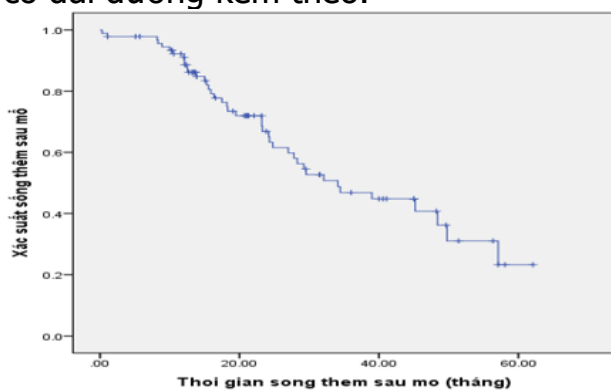

Đồ thi 3.1. Thởi gian sông thêm sau mổ cắt khôi tá tuy theo Kaplan-Meier.

Nhận xét: Thời gian sống sau 1 năm $(92,1 \%), 3$ năm $(45,6 \%), 5$ năm $(24,7 \%)$. Trung bình 36,2 tháng

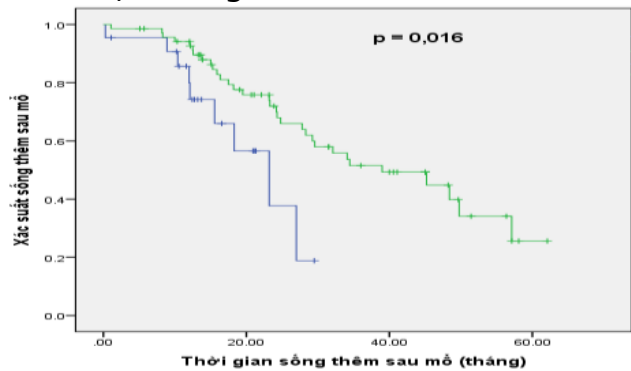

Đồ thị 3.2. Thớ gian sông thêm theo KaplanMeier với di căn hach vùng

Nhận xét: Có sự khác biệt giữa thời gian sống thêm giữa nhóm chưa di căn hạch (NO) và di căn hạch (N1) ( $p=0,016)$.

Bảng 3.2. Kêt quả giải phẫu bệnh sau mổ

\begin{tabular}{|c|c|c|}
\hline Giải phâu bệnh & $\mathbf{n}(\mathbf{8 4})$ & Tỉ lệ (\%) \\
\hline Kích thước u (cm) & & \\
\hline$\leq 5 \mathrm{~cm}$ & 36 & 42,9 \\
\hline$>5 \mathrm{~cm}$ & 48 & 57,1 \\
\hline Mô bệnh học & & \\
\hline Ung thư bóng Vater & 44 & 52,4 \\
\hline Ung thư đâu tụy & 20 & 23,8 \\
\hline Ung thư đường mật & 16 & 19,0 \\
\hline GIST tá tràng & 1 & 1,2 \\
\hline U nhú ống tụy (IPMN) & 3 & 3,6 \\
\hline Giai đoạn U & & \\
\hline T1 & 2 & 2,4 \\
\hline T2 & 33 & 39,3 \\
\hline
\end{tabular}

\begin{tabular}{|c|c|c|}
\hline T3 & 45 & 53,6 \\
\hline T4 & 4 & 4,7 \\
\hline Hạch & & \\
\hline N0 & 20 & 23,8 \\
\hline N1 & 64 & 76,2 \\
\hline
\end{tabular}

Nhân xét: Ung thư bóng Vater hay găp nhất (52,4\%), tiếp đến là ung thư đâu tụy $(23,8 \%)$; U ở giai đoạn T2, T3 là chủ yếu $(92,9 \%)$.

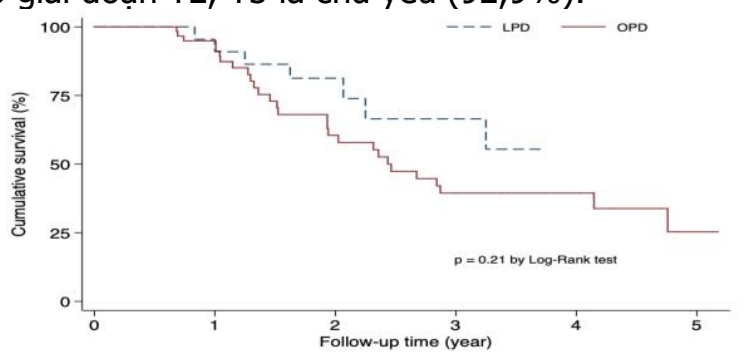

Đồ thị 3.3. Thời gian sông thêm sau mổ căt khôi tá tưy ơ hai nhóm PTNS và mổ mơ theo Kaplan-Meier.

Nhận xét: Không có sự khác biệt về thời gian sống thêm sau mổ giữa nhóm PTNS và PT mở với $\mathrm{p}=0,21$

Bảng 3.3. Phương trình hôi quy Cox tìm hiểu các yêu tố liên quan đến thời gian sống thêm sau mô.

\begin{tabular}{|c|c|c|}
\hline Các biến & HR (95\% CI) & p-value \\
\hline Kích thước U & $\begin{array}{c}1,25 \\
(0,81-1,31)\end{array}$ & 0,11 \\
\hline Giai đoạn U & $\begin{array}{c}1,81 \\
(1,06-3,67)\end{array}$ & 0.061 \\
\hline Hạch (N1 vs. N0) & $2.56(1.01-6.49)$ & 0.047 \\
\hline Giới (nam vs. nữ) & $0.60(0.30-1.21)$ & 0.16 \\
\hline $\begin{array}{c}\text { Nhóm tuối (> 65 } \\
\text { tuổi vs. } \leq 65 \text { tuổi) }\end{array}$ & $\begin{array}{c}3.93 \\
(1.63-9.42)\end{array}$ & $<0.01$ \\
\hline $\begin{array}{c}\text { Thời gian mố ( } 5 \text { 5 } \\
\text { giờ vs. > 5 giờ) }\end{array}$ & $\begin{array}{c}2.01 \\
(1.04-3.19)\end{array}$ & 0.065 \\
\hline $\begin{array}{c}\text { Tiếu đường } \\
\text { (có vs. không) }\end{array}$ & $\begin{array}{c}0.57 \\
(0.24-1.32)\end{array}$ & 0.19 \\
\hline
\end{tabular}

List of abbreviations: HR: Hazard Ratio; CI: Confidence Interval

Nhânn xét: Thời gian sống thêm sau mổ liên quan với nhóm tuổi (> 65 tuổi vs. $\leq 65$ tuổi), hạch (N1 vs. N0).

\section{BÀN LUÂ̂N}

Kết quả nghiên cứu về đặc điểm chung của bênh nhân được phẫu thuật cắt khối tá tụy (bảng 3.1) cho thấy các tổn thương ác tính ở vùng đầu tụy tá tràng chủ yếu gặp ở người trên 40 (92,5\%), nam gặp nhiêu hơn nữ, các bệnh nền kèm theo thường gặp là đái đường, cao huyết áp, hô hấp và tim mạch. Tuy nhiên các bệnh nhân đều được đánh giá ở ASA 1 đến 3, không có trường hợp nào ASA 4,5 vì đây là phấu 
thuật lớn, phức tạp. Phẫu thuật nội soi hỗ trơ ở 22 trường hợp, 64 trường hợp được phẫu thuật mở bao gồm có hay không bảo tồn môn vị.

Bảng 3.2. về kết quả giải phẫu bệnh cho thấy ung thư bóng Vater là tổn thương hay gặp nhất $(52,4 \%)$, tiếp đến là ung thư đầu tụy $23,8 \%$, tổn thương ác tính ở phần thấp ống mật chủ $19,0 \%$, ở tá tràng ít gặp hơn cả. Về giai đoạn u cho thấy các bệnh nhân của chúng tôi chủ yểu ở giai đoạn T2 và T3 $(92,9 \%)$ và $76,2 \%$ các trường hợp có hạch N1. Qua đó cho thấy các bệnh nhân được phẫu thuật cắt khối tá tụy trong nghiên cứu của chúng tôi ở giai đoạn không còn sớm, điêu này đã làm ảnh hưởng đến tiên lượng thời gian sống thêm sau mổ nhất là thời gian 5 năm. Các nghiên cứu cho thây rằng, thời gian sống thêm sau phẫu thuật cắt khối tá tụy phụ thuộc vào nhiều yếu tố như: bản chất khối u là ung thư Vater, ung thư đầu tụy, ung thư ống mật chủ hay ung thư tá tràng, độ xâm lấn của khối u $(T)$, di căn hạch $(\mathrm{N})$, giai đoạn bệnh, độ biệt hóa tế bào, bờ cắt tụy và tình trạng xâm lẩn mạch máu của khối u và trong số các tổn thương ác tính ở vùng đầu tụy tá tràng thì ung thư bóng Vater là loại tổn thương có tiên lượng tốt hơn với thời gian sống thêm sau mổ 5 năm từ 30 đến $50 \%$ nhưng phải chưa có di căn hạch [1], [2], [3].

Nghiên cứu của Juan Fabregat và cộng sự ở 204 trường hợp phẫu thuật cắt khối tá tụy để điều trị ung thư biểu mô tuyến tụy cho thấy thời gian sống thêm sau mổ trung bình là 2,54 năm, tî lệ sống thêm sau 5 năm là $13,55 \%$. Khi nghiên cứu về các yếu tố nguy cơ tử vong tác giả nhận thấy: giới tính nữ, không phải tuyền máu trong phẫu thuật, cắt bỏ được hơn 15 hạch bạch huyết và sử dụng hóa chất điều trị bổ trợ là những yếu tố làm cho tiên lượng dài hạn tốt hơn $(\mathrm{p}$ < $0,005)$ và kết luận nạo vét hạch phải được thực hiện khi phẫu thuật cắt khối tá tụy để điều trị ung thư [6].

Về thời gian sông thêm sau mổ đồ thị 3.1 trong nghiên cứu của chúng tôi cho thấy: Thời gian sống thêm sau mổ 1 năm là $92,1 \%$, 3 năm là $45,6 \%$ và sau 5 năm là $24,7 \%$ đã cao hơn so với nghiên cứu của Nguyễn Tấn Cường (2004), Nguyển Ngọc Bích (2014) và Hồ Văn Linh (2016). Trong nghiên cứu của Nguyễn Ngọc Bích thời gian sống thêm sau mổ 1 năm, 3 năm và 5 năm lần lượt là $65 \%, 34,1 \%$ và $16,6 \%$ [3], Hồ Văn Linh nghiên cứu trên 44 bệnh nhân được cắt khối tá tụy do ung thư bóng Vater có thời gian sống trung bình sau mổ là 36,8 tháng, sống thêm 5 năm là 18,5\% [5], Nguyễn Tấn Cường thời gian sống thêm sau mổ là 29,7 tháng và sống trên 5 năm là 1 bệnh nhân (4,3\%) [4]. Từ kết quả các nghiên cứu trên cho thấy, tiên lượng sống thêm 5 năm sau mổ cắt khối tá tụy đã có sự cải thiện rõ ràng trong những năm gần đây. Tỉ lệ này đã tăng từ 4,3\% lên $16,6 \%, 18,5 \%$ và $24,7 \%$ trong nghiên cứu của chúng tôi.

Yếu tố nào ảnh hưởng đến thời gian sống thêm sau mổ được trả lời trong nghiên cứu của chúng tôi ở đồ thị 3.2 về thời gian sống thêm sau mổ theo di căn hạch vùng đã được so sánh giữa hai nhóm cho thấy có sự khác biệt rõ ràng về thời gian sống thêm giữa nhóm chưa di căn hạch (NO) và di căn hạch (N1) với $p=0,016$. Chính vì vậy mà chẩn đoán sớm, chỉ định kịp thời, lấy bỏ hết tổn thương và nạo vét hạch là những việc cần làm khi cắt khối tá tụy để điều trị cho bất kỳ một tổn thương ắc tính nào ở vùng này. Vì nạo vét hạch ngoài ý nghĩa đảm bảo tính triệt căn còn có ý nghĩa để đánh giá, tiên lượng giai đoạn bệnh cũng như lựa chọn phác đồ hóa trị phù hợp cho người bệnh sau mổ.

Theo sự đồng thuận của hiệp hội phẫu thuật Tụy quốc tế (International Study Group on Pancreatic Surgery - ISGPS) năm 2014 , định nghĩa nạo vét hạch tiêu chuẩn trong cắt khối tá tụy do ung thư bao gồm các nhóm hạch 5,6 , $8 a, 12 b 1,12 c, 13 a, 13 b, 14 a, 14 b, 17 a, 17 b$. Nếu nạo vét hạch mở rộng sẽ bao gồm nhóm 9 (quanh động mạch thân tạng), nhóm 7 (động mạch vị trái), nhóm 11 động mạch lách. Kỹ thuật nạo vét hạch tiêu chuẩn có số lượng từ 13 đển 17 hạch, trung bình là 15 hạch, do đó nạo vét hạch tiêu chuẩn đảm bảo được số lượng hạch lấy được. Một nghiên cứu tổng hợp của Sabater năm 2014 dựa trên số liệu tổng hợp của 14 báo cáo với 3093 bệnh nhân đã kết luận rằng, số lượng hach trung bình nạo vét được trong phẫu thuật cắt khối tá tụy > 15 hạch mới có ý nghĩa đảm bảo tính triệt căn [6], [7].

Tổng cộng 84 bệnh nhân u vùng đầu tụy và quanh bóng Vater từ 26 đến 80 tuổi đủ tiêu chuẩn đã được tham gia vào nghiên cứu so sánh, trong đó 22 bệnh nhân được PTNS và 62 bệnh nhân được PT mở kinh điển tương ứng. Không có sự khác biệt về giới giữa nhóm PTNS và PT mở, không có sự khác biệt về các bệnh phối hợp giữa hai nhóm và không có sự khác biệt về các chỉ số sinh hóa và công thức máu đầy đủ giữa hai nhóm nhưng tuổi trung bình ở nhóm mổ mở cao hơn có ý nghĩa thống kê so với nhóm mổ nội soi $(p<0,05)$. Nghiên cứu của chúng tôi không tìm thấy sự khác biệt về kết quả sống sót ngắn hạn và dài hạn giữa PTNS và PT mở với $p$ = 0,21 (đồ thị 3.3). Tỷ lệ sống thêm 1 năm khá 
giống nhau ở nhóm PTNS (90,9\%) và PT mở (94,9\%). Tỷ lệ sống thêm 3 năm ở nhóm mổ nội soi là $(66,5 \%)$ cao hơn đáng kể so với nhóm mổ mở (39,5\%). Tuy nhiên, kiểm tra thứ hạng nhật ký cho thây không có sự khác biệt giữa tỷ lệ sống sót theo thời gian ( $p>0,05)$, phù hợp với một số nghiên cứu trước đây cho rằng tỷ lệ sống sót của bệnh nhân được PTNS có xu hướng cao hơn so với bệnh nhân sử dụng PT mở, nhưng sự khác biệt khồng có ý nghĩa thống kê.

Các nghiên cứu cho thây bệnh nhân được cắt khối tá tụy bằng PTNS giảm mất máu, giảm tỉ lệ nhiễm trùng vết mổ, giảm chăm sóc đặc biệt và thời gian nằm viện ngắn hơn, phục hổi sau mổ sớm hơn do vậy có thể được tiếp cận với biện pháp hóa trị sớm hơn so với nhứng trường hợp được PT mở. Tuy nhiên một thực tế lâm sàng là những bệnh nhân được chỉ định PTNS cắt khối tá tụy thường có kích thước u nhỏ và u ở giai đoạn sớm hơn so với những trường hợp PT mở và thời gian PTNS dài hơn so với PT mở [9].

Nghiên cứu của Stauffer JA và cộng sự ở 251 bệnh nhân ung thư đầu tụy trong đó 193 mổ mở và 58 mổ nội soi cho thây thời gian PTNS cắt khối tá tụy dài hơn so với mổ mở nhưng tỉ lệ mất máu và truyền máu thấp hơn. Những bệnh nhân mổ mở thì có kích thước khối u lớn hớn bệnh nhân mổ nội soi. Các biến chứng sau mổ, thời gian chăm sóc đặc biệt, thời gian nằm viện sau mổ là như nhau và thời gian sống thêm sau mổ là 20,3 tháng với mổ mở, 18,5 tháng đối với mổ nội soi. Tỉ lệ sống sót sau mổ ở hai nhóm tương tự nhau: mổ mở 1 năm $68 \%$, 3 năm 24\%, 5 năm $15 \%$ với mổ nội soi 1 năm là $67 \%, 3$ năm $43 \%$ và $32 \%$.

Trong nghiên cứu, chúng tôi xác định một số yếu tố liên quan đến kết quả sống sót lâu dài của bệnh nhân, những yếu tố này cần được xem xét để cải thiện điều trị cho bệnh nhân u vùng đâuu tụy tá tràng và quanh bóng Vater trong tương lai. Trên từng bước mô hình nguy cơ tỷ lệ Cox đa biến, các yếu tố có ý nghĩa liên quan đến sự sống còn của bệnh nhân u vùng đâu tụy và quanh bóng Vater là giai đoạn $\mathrm{N} 1(\mathrm{HR}=2,65$, $95 \% \mathrm{CI}=1,01-6,49)$, nhóm tuổi $>65$ tuổi (HR = $3,93,95 \%$ CI $=1,63-9,42$. Giai đoạn u có xu hướng liên quan với thời gian sống thềm sau mổ nhưng sự khác biệt không có ý nghĩa thống kê. Các yếu tố khác như giới, kích thước u, thời gian phẫu thuật, bệnh tiểu đường không liên quan đến thời gian sống thêm sau mổ cắt khối tá tụy.

Chúng tôi nhận thấy nguy cơ tử vong không lên liên quan đến thời gian phẫu thuật, tuy nhiên chúng tôi cho rằng cần một nghiên cứu với kích thước mẫu lớn hơn và tập trung vào một tình trạng và giai đoạn cụ thể của bệnh có thể cho thấy ảnh hưởng của thời gian phấu thuật đến kết quả của phẫu thuật cắt khối tá tụy vì thực tế khi phẫu thuật cho thấy những khối u lớn, ở giai đoạn muộn, có nhiều hạch cần thời gian phẫu thuật dài hơn so với những khối u nhỏ, còn sớm và ít hạch. Một thực tế lâm sàng cho thấy rằng, bệnh nhân ở giai đoạn N1 có tình trạng nặng hơn bệnh nhân ở giai đoạn N0. Ngoài ra, chúng tôi cũng nhận thấy có sự khác biệt về nguy cơ tử vong giữa nhóm từ 65 tuổi trở lên và nhóm từ 65 tuổi trở xuống, trong đó nhóm bệnh nhân lớn tuổi có nguy cơ tử vong cao hơn so với nhóm bệnh nhân trẻ tuổi. Điều này phù hợp với kết quả trong nghiên cứu của một số tác giả, báo cáo rằng tuổi tác tăng lên liên quan đến nguy cơ tử vong cao hơn ở những bệnh nhân có khối u vùng đầu tụy [7], [8].

\section{KẾT LUÂN}

Phẫu thuật cắt khối tá tụy để điềuv trị các khối u vùng đầu tụy tá tràng và quanh bóng Vater an toàn và hiệu quả. Thời gian sống thêm sau mổ 1 năm là $92,1 \%, 3$ năm là $45,6 \%$ và sau 5 năm là $24,7 \%$, thời gian sống thêm sau mổ liên quan đến nhóm tuối $>65$ và $<65$ tuổi; giai đoạn N0 và N1.

\section{TÀI LIÊU THAM KHẢO}

1. Albores- Saavedra J., Schwartz A.M., Batich K., et al. "Cancers of the ampulla of Vater: demographics, morphology, and survival based on 5,625 cases from the SEER program. Journal of surgical oncology 2009; 100(7), 598- 605.

2. Nimura, Y., Nagino, M., Takao, S., et al, (2012), Standard versus extended lymphadenectomy in radical pancreatoduodenectomy for ductal adenocarcinoma of the head of the pancreas: long-term results of a Japanese multicenter randomized controlled trial. Journal of hepato-biliary-pancreatic sciences, 19, 3, 230-241.

3. Nguyễn Ngọc Bích (2012), 'phẫu thuật cắt đâu tụy tá tràng, kinh nghiệm trên 160 trường hợp" Ngoại khoa 61, số $1-2$ - 3 tr 34- 42

4. Nguyễn Tấn Cường Võ Tấn Long, Nguyễn Mính Hải (2004) Ung thư nhú Vater: Kết quả điều trị phẫu thuật tại Bệnh viện Chợ Rẫy", Y học Thành phố Hồ Chí Minh , 8(3), tr. $125^{\circ}$ - 133.

5. Hồ Văn Linh (2016), "Đánh giá kết quả phẫu thuật cắt đầu tự tá tràng trong điêu trị ung thư bóng Vater", Luận án Tiển sĩ Y học, Trường đại học Y Dược, Đại học Huế

6. Juan Fabregat, juli Busquets, Nuria pela, et al (2010), "Surgical treatment of pancreatic adenocarcinoma using cephalic duodenocarcinoma. Long term follow upter 204 cases", Published by Elsivier Esparia, 88 (6) 374-382.

7. Tol, J. A., Gouma, D. J., Bassi, C., et al, (2014), Definition of a standard lymphadenectomy in surgery for pancreatic ductal adenocarcinoma: a consensus statement by the 
International Study Group on Pancreatic Surgery (ISGPS). Surgery, 156, 3, 591-600.

8. Jang, J. Y., Kang, M. J., Heo, J. S., et al, (2014), A prospective randomized controlled study comparing outcomes of standard resection and extended resection, including dissection of the nerve plexus and various lymph nodes, in patients with pancreatic head cancer. Annals of surgery,
259, 4, 656-664.

9. Song KB, Kim SC, Lee W, Hwang DW, Lee JH, Kwon J, et al. (2020), Laparoscopic pancreaticoduodenectomy for periampullary tumors: lessons learned from 500 consecutive patients in a single center. Surgical endoscopy, 34(3): 1343-52.

\section{NHÂN MỘT TRƯỜNG HỢP U ĐẠI BÀO CỦA XƯƠNG ĐÁ}

\section{TÓM TẮT}

Bệnh nhân nam 45 tuổi vào viên vì đau và sưng vùng góc hàm và vùng chẩm bên trái. Kèm theo ù tai, nghe kém và liệt VII ngoại biên trái. Qua khám lâm sàng, khảo sát CT/MRI và giải phẫu bệnh. Chẩn đoán xác định là u đai bào xương. Đây là khối u lành tính nhưng có tỷ lệ tái phát cao. Không có dấu hiệu điển hình, chẩn đoán xác đinh dựa vào giải phẫu bênh Phẫu thuật là lựa chọn hàng đầu trong điêu trị u đại bào xương.

Tư khóa: u đại bào xương, u xương thái dương.

\section{SUMMARY}

\section{A CASE REPORT: GIANT CELL TUMOR OF TEMPORAL BONE}

The patient who is 45 year old man with main complaint pain and swelling in the left mandibular mastoid region. In addition, he has hearing loss, fullness of ear, facial weakness into left side. We diagnosis giant cell tumor (GCT) of temporal bone by clinical symptoms, CT/MRI and biopsy. The GCT is benign tumor, but high recurrence rate after removing tumor. It is not typical signs and symptoms. We can do the diagnosis by pathology. The surgery is the most suitable option to cure giant cell tumor of temporal bone.

Keywords: Giant cell tumor, temporal bone tumor

\section{GIỚI THIỆU}

U đại bào xương (giant cell tumor) của xương thái dương là khối u xương nguyên phát hiếm găpp, thường tìm thấy ở trung tâm cốt hóa xương của đâu xương dài, nhưng hiếm gặp hơn ở xương sọ. Những khối u này thường lành tính, nhưng tiến triển tại chổ, thường làm mòn các xương xung quanh khi nó phát triển. Cho đến hiện nay hướng đến kiểm soát và điều trị chưa đầy đủ với sự phát triển cho u đại bào xương

\footnotetext{
*Bệnh viện Chợ Rẫy

Chịu trách nhiệm chính: Ngô Văn Công

Email: congtmh@gmail.com

Ngày nhận bài: 11.5.2021

Ngày phản biên khoa họ: 5.7.2021

Ngày duyệt bài: 16.7.2021
}

Ngô Văn Công*

vùng nền sọ và thái dương [4]. Hầu hết kiến thực điều trị hiện nay xuất phát từ điều trị các tổn thương xương dài và cột sống.

\section{CA LÂM SÀNG}

Tại Khoa Tai Mũi Hong - Bệnh viện Chơ Rẫy: tháng $5 / 2021$ có bênh nhân nam 47 tuổi vào viên vì đau và sưng vùng góc hàm và vùng chẩm bên trái. Lâm sàng với một khối sung to ở vùng góc hàm và tai bên trái. Kèm theo liệt VII ngoại biên bên trái và nghe kém, ù tai bên trái. Sau khi khám lâm sàng và đánh giá $\mathrm{CT} / \mathrm{MRI}$ xương thái dương thì phát hiện khối u kích thước lớn 10x10 $\mathrm{cm}$ hủy gần toàn bộ xương đá, đến màng não phần tiểu não và xoang sigma, khối u bao cả bó mạch cảnh bên trái, khối u xấm lấn hố chân bướm hàm trái. Tiền sử đã được phẫu thuật sinh thiết được thực hiện bởi khoa ngoại thần kinh vào năm 2019 với chẩn đoán u đỉnh xương đá, và kết quả mô bênh học là u đại bào xương. Chẩn đoán xác định là u đại bào xương đá xâm lấn hố dưới thái dương. Được hội chẩn với các chuyên khoa Tai Mũi Họng, ngoại thần kinh, mach máu và ung bướu. Chuyên khoa Tai Mũi Họng sẽ phẫu thuật giảm thể tích khối u và sẽ xạ trị hổ trợ sau phẫu thuật.

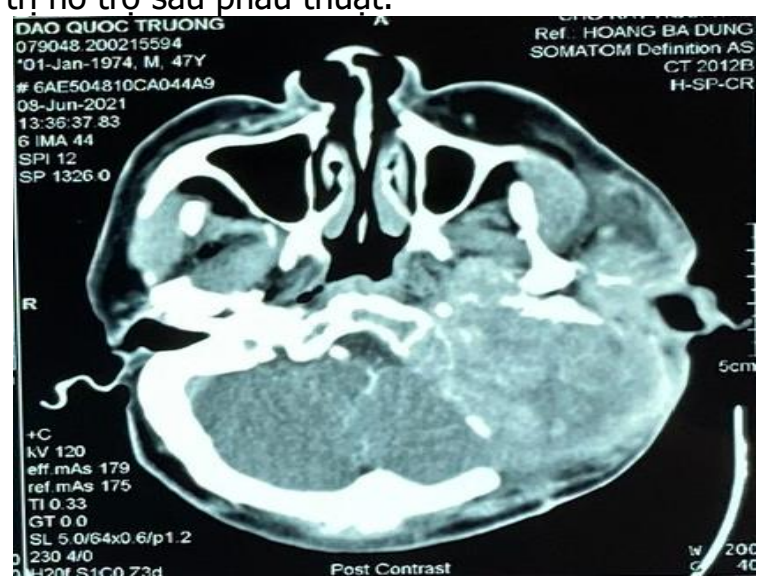

Hình 1: Khôi u hủy toàn bộ xương đá bên trái 